\title{
Heat gets turned up on climate research city
} some of the world's leading atmospheric science laboratories could cause the loss of irreplaceable data on climate change, and set back understanding of global warming by several years, according to scientists working at the US laboratories concerned.

"There's a distinct difference between terminating long-term programmes and shutting down short-term programmes," says Dave Hofmann, acting director of the Climate Monitoring and Diagnostics Laboratory (CMDL) in Boulder, Colorado. "If you go for a year without collecting the long-term data, you lose it for ever," he says.

CMDL is one of six environmental research laboratories in Boulder run by the National Oceanic and Atmospheric Adminment of Commerce, which Republicans in both houses of Congress would like to abolish, NOAA faces steep budget cuts - or even abolition (see Nature 375, 347; 1995).

As well as leading to gaps in the records of levels of greenhouse gas, ozone, aerosol and solar radiation kept by the laboratory, Congress's plans threaten to deal a blow to Boulder's economy, dominated by the concentration of government laboratories surrounding the University of Colorado.

The NOAA institutions under threat include the aeronomy laboratory, which has pioneered the study of ozone in the upper atmosphere, and the forecast systems and environmental technology laboratories, which each develop new technology for the National Weather Service and other users.

Like so many elements of the US research infrastructure, these laboratories have their roots firmly embedded in the Cold War: the aeronomy laboratory and the environmental technology laboratory known until 1993 as the wave propagation laboratory - were set up in the 1950 s because the US military wanted a better understanding of the upper atmosphere in order to improve its communications.

Department of Defense money still flows
Boulder, Colorado. Proposed budget cuts at istration (NOAA). As part of the Depart-

into most laboratories. But their priorities have shifted to reflect concern about the global environment. "It's a good example of how science marshals itself to meet societal needs," says Fred Fehsenfeld, an atmospheric chemist at the aeronomy laboratory.

Yet this new mission has now become politically contentious. Dana Rohrabacher (Republican, California), chair of the House energy and environment subcommittee which oversees NOAA, said earlier this month that global warming was "unproven, at best, and liberal claptrap, at worst".

Scientists at Boulder are particularly concerned by a clause in an authorization bill for NOAA drafted by Rohrabacher that would constrain research to "seasonal" climate trends. The limitation, says Hofmann, is designed to put pressure on "anything associated with global warming".

The Rohrabacher language is unlikely to pass into law, but the pressure will remain. If research into long-term trends were to be halted, says Hofmann, most of the CMDL staff would leave at once.

In response to the threat to their future, the environmental laboratories have returned to first principles to explain what is known and not known about global warming and ozone depletion. "Scientists have tended to ignore the Rush Limbaugh types who say "this is just a load of crap", says Hofmann, referring to the influential radio talk-show host who argues that there is no problem of ozone depletion.

The laboratories have also been seeking political support by pointing out that their work does not necessarily lead to more government regulation. Research at Boulder on the use of methyl bromide as a fumigant in Californian agriculture, for example, indicated that it was being used safely, and supported the case against regulation.

John Bates, a meteorologist at the climate diagnostics centre - another NOAA facility at Boulder - is about to publish research results on the stabilizing role of water vapour in the atmosphere

\section{Security alert at French ion accelerator}

Paris. The national heavy-ion accelerator at Caen in France (GANIL) has been shut down following the discovery of a failure in a safety system designed to prevent staff from entering a cyclotron while it is in operation, and thus being exposed to ionizing radiation.

The failure allowed access to one of GANIL's two accelerators - which was running at the time - for almost half an hour before being noticed fortuitously. It is thought to have been caused by software that had been recently modified.

No-one is thought to have entered the accelerator during this period, but management at the reactor, which is jointly Recherche Scientifique and the Commissariat à l'Energie Atomique (Atomic Energy Commission), say that staff dosimeters have yet to be read.

The Department of Safety of Nuclear Installations, which made public the incident last week, rated it at 2 on the international scale from zero to 6 for nuclear accidents. It also ordered that the whole facility should be shut down pending proposals from its operators on how to prevent such an incident from happening again.

Declan Butler operated by the Centre National de la which he predicts will please those who claim that the dangers of global warming have been overstated. As a Democrat, he does not agree with their goals; but "it's important to see us as impartial scientists trying to understand nature better," he says.

As well as the research itself, pending cuts also threaten the comfortable lifestyle of the attractive and well-heeled city of Boulder, where three-fifths of the population have university degrees, and folks still leave their doors unlocked at night.

For example, 800 staff at a laboratory belonging to the National Institute of Standards and Technology - also part of the Commerce Department - face an uncertain future, with one Republican plan in Congress calling for outright closure.

At nearby Golden, the Department of Energy's 1,000-strong National Renewable Energy Laboratory works on programmes likely to lose at least half their funding. The University of Colorado, which received $\$ 130$

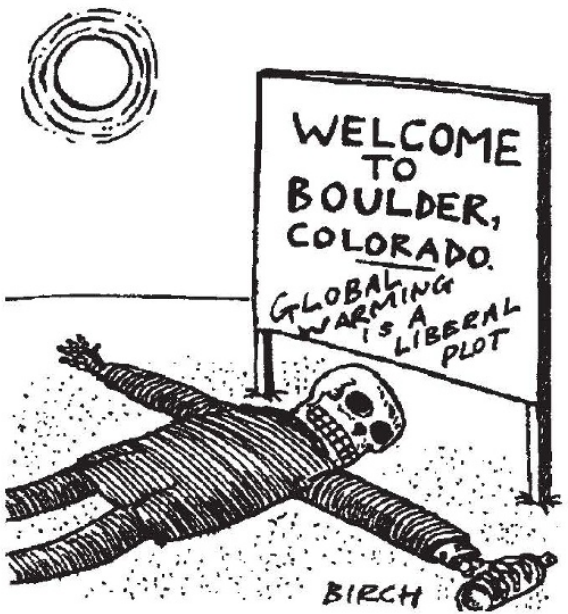

million in federal research last year, expects cuts in support from all its main funding agencies except the National Science Foundation (NSF). Fortunately for Boulder, the NSF is also the main source of finance for the National Center for Atmospheric Research, the city's largest employer after the university - with 1,060 staff.

Cities such as Boulder normally receive solid support from congressmen and senators worried that, without them, their states will become intellectual and economic backwaters. But some staff at the laboratories say Colorado's two Republican senators have shown little interest, and they fear the city is about to suffer for its reputation as a hotbed of liberalism in this conservative state.

Others are more sanguine. Steve Clifford, director of the environmental technology laboratory, points out that the budget and government reform processes both have a long way to go in Washington. "What I'm interested in is the quality of the debate," he says. "If it's high enough, we'll come out okay."

Colin Macilwain 